\title{
Assessment of Housing Quality in Ede, Nigeria
}

\author{
Adewale YOADE ${ }^{1^{*}}$--- Olabisi ADEYEMI ${ }^{2}$--- Olawunmi YOADE ${ }^{3}$ \\ ${ }^{1, s}$ Department of Urban and Regional Planning, Wesley University Ondo, Nigeria. \\ ${ }^{2}$ Email:yoadewale@yahoo.com \\ ${ }^{2}$ Department of Urban and Regional Planning, Federal Polytechnic Ado-Ekiti, Ekiti State, Nigeria.
}

\begin{abstract}
This study examined the housing quality in Ede, Nigeria and the impacts of urbanization on environmental degeneration of urban built environment. A total of 388 housing units, consisting of 236, 78 and 74 units were drawn for sampling from the high, medium and low density areas of the study area, respectively. The secondary data involved available census data, official documents and other relevant secondary data were obtained from existing literature, on books and journals. The study established that majority (62.6\%) of the respondents are female while $37.3 \%$ of the respondents are male in the study area. Findings established that $63.9 \%$ and $55.1 \%$ have no educational qualification and primary education in high and medium density areas respectively while in contrast majority (91.1\%) in low density area have tertiary education in the study area. Findings also revealed that householdsize has a significant influence on the overall housing quality in the study area. The study concluded that it is imperative to check and prevent further decay for good living and working environment.
\end{abstract}

Keywords: Urbanization, Environment, Housing quality, Infrastructural facilities and amenities.

Licensed: This work is licensed under a Creative Commons Attribution 4.0 License.

\section{Introduction}

Providing adequate housing is a concern, not only of individuals but also of governments (UN-Habitat, 2006). Although, global data on housing quality is limited, yet the United Nations (1996) asserts that the cost of doing nothing is detrimental in all spheres because the urban slums are potential breeding places for social and political unrest. Thus, international concerns have been growing over the deteriorating housing conditions in urban areas of developing nations. It is estimated that over a billion of the world's city residents live in insufficient quality housing, mostly in the sprawling slums and squatter settlements in developing countries (UN - Habitat, 2006). Such areas are regarded as areas of most visible expressions of human poverty (Yoade and Adeyemi, 2015).

In spite of the pathetic housing situation experienced in Nigeria, attempts by the various housing professionals including architects, planners and government agencies to improve the quality of housing have not yielded any desirable result. Rather than providing a culturally determined as well as user's responsive dwellings, most housing developments have been based on planners' standard. Attention is paid to what the buildings look like and not how they will be used in practice and their cultural fit. While appearance is important, houses must serve the everyday needs of the people for whom they are designed (Muller, 1984; Gyuse, 1993).

However, it has been affirmed that adequate and good quality housing provides the foundation for stable communities and social inclusion, and that housing should reflect the cultural, social and economic values of a society as it is the best physical and historical evidence of civilization in a country (Onibokun, 1982; Onibokun, 1985; Foster, 2000). In its entirety, housing is thus connected with the essence of life as it affects the whole of 
life in every way. Whereas, previous studies have underscored the need to improve the quality of housing, only a few of them within the Nigeria context had actually examined and stressed on the specific impact and relevance of households' socio-economic as well as socio-cultural attributes on housing quality. This study is thus a contribution in this direction. Using Ede as a case in point, the main objective of this study is to examine the effect of socio-economic and socio-cultural parameters in the determination of residential quality in Nigeria (Yoade, Olayiwola and Popooala, 2013).

Series of studies have also been conducted on the quality of housing: (see: Agbola, 1998; Adeleye, 2012; Aduda, 2002; Jiboye, 2004). Of much relevance is Jiboye (2009a) in his study of users' house-hold size and housing quality in Osogbo, Nigeria. He characterized the form and physical environment of slum and concluded that government in its wisdom has to re-organize their attitude and approach to slum eradication. From the foregoing, less emphasis has been given to the relevance of socio-economic together with sociocultural factors on housing quality. The example of an emerging but traditional city like Ede is yet to be examined.

\section{Literature Review}

Housing, which is often defined as a multi-dimensional bundle of services, is also a bundle of contradictions and paradoxes. This is because the exogenous variables, acting in concert with or in contradistinction from the endogenous variables, often create paradoxical situations (Agbola and Agunbiade, 2007).

Likewise, Agbola (1998) concludes that housing is a combination of characteristics which provide a unique home within any neighborhood; it is an array of economic, social and psychological phenomena. In other words, housing could be seen as a multidimensional package of goods and services extending beyond shelter itself. The need to appreciate the relevance of a habitable (qualitative) housing therefore, requires an understanding of the concept of 'quality' which according to Onion, cited in Afon (2000), "is a mental or moral attribute of a thing which can be used when describing the nature, condition or property of that particular thing". Mccary, cited in Jiboye (2004), noted that reaching a definition of quality depends not only on the user and his or her desires, but also on the product being considered. In essence, quality is a product of subjective judgment which arises from the overall perception which the individual holds towards what is seen as the significant elements at a particular point in time ( Olayiwola, Adeleye and Jiboye, 2006).

In assessing the quality or suitability of housing, previous qualitative studies have identified some criteria as relevant indicators for quality evaluation in residential development. Among such is Abloh (1980), who noted that housing acceptability should take into account, type of construction, materials used, and amount of space, services and facilities, condition of facilities within and outside dwelling, function and aesthetics among many others. Ebong (1983) identified aesthetics, ornamentation, sanitation, drainage, age of building, access to basic housing facilities, burglary, spatial adequacy, noise level within neighbourhood, sewage and waste disposal, air pollution and ease of movement among others, as relevant quality determinants in housing. However, Hanmer et al. (2000), conclude that qualitative housing involves the provision of infrastructural services which could bring about sustainable growth and development through improved environmental conditions and improved livelihood.

In Nigeria, and other third world nations, the need to provide qualitative housing based on user's responsive and culturally determined considerations - particularly for the vast majority of the urban population is central to the achievement of sustainable cities and human development. Nonetheless, the use of relevant information evolving from human values in housing development has been negligible. Yet, they are critical in guiding housing improvement and development. Perhaps, this study could bridge this gap by providing explanations for the relevance of users' household-size in residential quality development in Nigeria. Previous studies have indicated that a more appropriate method of evaluating the quality of the built environment is through the affective responses based on the user's assessment (Ilesanmi, 2005).

However, good quality housing standards are essential and basic to planning. These, not only ensure the safety and wellbeing of people but also promote beauty, convenience and aesthetics in the overall built-up environment. Good quality housing means more than a roof over one's head. It also means adequate privacy; adequate space, physical accessibility; adequate security, security of tenure, structural stability and durability; adequate lighting, heating and ventilation; adequate basic infrastructure, such as water supply, sanitation and waste-management facilities; suitable environmental quality and health-related factors; and adequate and accessible location with regard to work. All of these should be available at an affordable cost and should be determined together with the people concerned (Lewin, 1981; Olotuah, 2006; UN - HABITAT, 2006).

Furthermore, poor housing has repercussions across a whole range of other aspects of life, such as employment, as housing not only fulfills the basic human physical need for shelter but also satisfies social requirements. A house provides a center for an individual and the basis for family life, emerging as an important symbol of social standing and aspirations. Thus, the fulfillment of housing quality needs is a complex process. A good housing, therefore, must possess a general layout of good appearance, and comply with the general customs and habits of the people without which it may turn into a slum (Lucas, 1990; Sholamith, 2000; UNICEF, 2001). 
Yet the sufficient and good quality provision of this basic need elude a high proportion of the population of these countries (Abiodun, 1985; Olayiwola et al, 2005; National Housing Policy, 2006). Housing is a basic human need. The understanding of its concept, as well as its components that provide for good quality, as is germane to this study is evaluated. In this study therefore, qualitative evaluation will be based on user's assessment of the physical criterion of housing. This will consider among other variables identified above, the quality of housing in terms of adequacy of basic infrastructures, suitability of the building design; integrity of the building elements, as well as that of fixtures within the dwellings. It is against this backdrop that this study examined housing quality in Ede, Nigeria.

\section{Study Area}

Ede is a town in Osun State, southwestern Nigeria. It lies along the Osun River at a point on the railroad from Lagos, 112 miles $(180 \mathrm{~km}$ ) southwest, and at the intersection of roads from Oshogbo, Ogbomosho, and Ife. Ede is one of the older towns of the Yoruba people. It is traditionally said to have been founded about 1500 by Timi Agbale, a hunter and warlord sent by Alaafin (King) Kori of Old Oyo (Katunga), capital of the Oyo empire, to establish a settlement to protect the Oyo caravan route to Benin $(127 \mathrm{miles}$ [204 $\mathrm{km}]$ to the southeast), a purpose similar to that of other Nigerian towns. Nearby towns include Awo, Iragberi and Oshogbo. The study area lies between Lat. $7^{\circ} 42^{1} \mathrm{~N}$ and $7^{\circ} 47^{1} \mathrm{~N}$ and Long. $4^{\mathrm{o}} 21^{1}$ and $4^{\circ} 27^{1}$ East of Greenwich Meridian. Based on 2006 Population Census, the population of the area was put at 159,307. Most of the inhabitants of the area engaged in subsistence farming and trading. Ede is well known as a hospitable land. Locally made food includes "Eko and Ila". Also sons and daughters of Ede can be found all over the world and works of lives. There are several compounds in Ede towns including Ile Agate, Agboja, Imole, Ile Idigba, Ile Obadina, Ile Alusekere, Ile Yemope, Ile Mogaji, Ile Oluyinka, Ile babanla Pegba, Jagun Olukosi, Ile Olorigogoro, Ile Alagbede, etc .

\section{Methodology}

The study area, Ede consists of three residential zones identified based on the pattern of city growth - the high, (zone A), medium ((zone B) and low area (zone C) (Jiboye, 2009b; Jiboye, 2009c; Jiboye, 2010). Housing samples were taken from a total of 3,888 housing units identified within these zones in the study. The data for this study were collected through administration of questionnaires on residents in the study area. The eleven (11) political wards in Ede North Local Government were divided according to the stratified residential areas six (6) wards in the high density area, three (3) wards in the medium density area and two (2) wards in the low density area. In the administrative of questionnaires, one (1) ward was sampled in each residential zone. However, in the three (3) selected wards, every 10 building was selected from which a household head was surveyed. From the process, 388 questionnaires were administered to comprising, 236, 78 and 74 in high (A), medium (B) and low density (C) areas respectively. The data collected were collected were analyzed using frequency distribution, mean and analysis of variance (ANOVA) Table 1.

Table-1. Distribution and selection of samples in Osogbo.

\begin{tabular}{l|l|l|l|l}
\hline Residential Zones & No of quadrates & $\begin{array}{l}\text { No of Housing Unit } \\
\text { per quadrate }\end{array}$ & $\begin{array}{l}\text { Total units } \\
\text { per zone }\end{array}$ & $\begin{array}{l}\text { Number of samples } \\
\text { retrieved per zone } \\
\mathbf{1 0} \%)\end{array}$ \\
\hline High (A) & 157 & 8 & 2368 & 236 \\
\hline Medium (B) & 19 & 55 & 780 & 78 \\
\hline Low (C) & 9 & 75 & 740 & 74 \\
\hline Total & 185 & 138 & 3,888 & 388 \\
\hline Source: Author's Field Work, 2016.
\end{tabular}

\section{Analysis and Discussion}

\section{Background Information of the Respondents'}

Findings established that majority $(62.6 \%)$ of the respondents are female while $37.3 \%$ of the respondents are male in the study area. In disaggregated manner, $81.1 \%, 61.5 \%$ and $57.2 \%$ of the respondents are female in zone $\mathrm{A}$, zone $\mathrm{B}$ and zone $\mathrm{C}$ respectively in the study area. Also, majority $(62.3 \%)$ are of age 50 years and above while just $2.1 \%$ are below 20 years of age in the study area. In disaggregated manner, $52.9 \%$ of the respondents are 50 years and above in zone A while $55.1 \%$ and $75.6 \%$ of the respondents are above 50 years of age in zone $\mathrm{B}$ and zone $\mathrm{C}$ respectively in the study area. The study revealed that $41.8 \%$ have no formal education while $25.0 \%$ of the respondents have primary education at all in the study area. In disaggregated manner, $63.9 \%$ and $55.1 \%$ have no educational qualification and primary education in zone A and zone B respectively while in contrast most $(91.9 \%)$ in Zone $\mathrm{C}$ have tertiary education in the study area. The implication of this is that zone $\mathrm{C}$ is dominated by educated elites.

Findings revealed that the Yoruba ethnic origin predominates over all other ethnic origins residing in the study area. This accounts for $98.7 \%$ of the respondents treated as a group. In disaggregated manner, it accounts for $97.9 \%$ in zone $\mathrm{A} ; 100 \%$ in zone B and $93.2 \%$ in zone $\mathrm{C}$. These figures indicate that zones A and B 
- which are the core and intermediate areas, have more respondents of the Yoruba socio-cultural origin than zone $\mathrm{C}$ (the newly developed area). Considering the size of households in the study area, the result indicates that $48.5 \%$ of households have an average of six (7) persons or more per family. This value accounts for $78.0 \%$ in zone A (high) $71.8 \%$ in zone B (medium) while $86.5 \%$ in zone C (low) have between 5 and 6 as household size. The values show that zones $\mathrm{A}$ and $\mathrm{B}$, which are primarily inhabited by the indigenes and traditional people of the study area, had larger proportions of household size than zone $\mathrm{C}$ which is occupied by educated elites Table 2.

This result essentially provides the basis for the polygamous and extended family structure, typical of the traditional Yoruba ethnic group in Nigeria. A structure opposed to the nuclear family structure of the western culture - where a household consists of the father, mother and an average of two to three children. This finding thus substantiates earlier assertions by Goffman (1959) and Muller (1984), indicating the level of importance attached to the extended family structure among the Yoruba ethnic group in Nigeria.

Table-2. Background Information of the Respondents'.

\begin{tabular}{|c|c|c|c|c|c|c|c|c|}
\hline Ratings & $\begin{array}{l}\text { High } \\
\text { Density (A) } \\
\text { Frequency }\end{array}$ & $\%$ & $\begin{array}{l}\text { Medium } \\
\text { Density(B) } \\
\text { Frequency }\end{array}$ & $\%$ & $\begin{array}{l}\text { Low } \\
\text { Density(C) } \\
\text { Frequency }\end{array}$ & $\%$ & Total & $\%$ \\
\hline \multicolumn{9}{|l|}{ Sex } \\
\hline Male & 101 & 42.8 & 30 & 38.4 & 14 & 18.9 & 145 & 37.3 \\
\hline Female & 135 & 57.2 & 48 & 61.5 & 60 & 81.1 & 243 & 62.6 \\
\hline \multicolumn{9}{|l|}{ Age } \\
\hline $\begin{array}{l}\text { Below } 20 \\
\text { years }\end{array}$ & 7 & 2.9 & 1 & 1.2 & - & - & 8 & 2.1 \\
\hline 21-30 years & 22 & 9.3 & 6 & 7.7 & - & - & 28 & 7.2 \\
\hline $31-40$ years & 31 & 13.1 & 13 & 16.7 & 4 & 5.4 & 48 & 12.4 \\
\hline $41-50$ years & 51 & 21.6 & 15 & 19.2 & 14 & 19.0 & 80 & 20.6 \\
\hline $\begin{array}{l}50 \text { years } \\
\text { and above }\end{array}$ & 125 & 52.9 & 43 & 55.1 & 56 & 75.6 & 224 & 57.7 \\
\hline \multicolumn{9}{|c|}{ Educational Status } \\
\hline $\begin{array}{l}\text { No } \\
\text { Education }\end{array}$ & 151 & 63.9 & 11 & 14.1 & - & - & 162 & 41.8 \\
\hline $\begin{array}{l}\text { Primary } \\
\text { School }\end{array}$ & 53 & 22.5 & 43 & 55.1 & 1 & 1.2 & 97 & 25.0 \\
\hline $\begin{array}{l}\text { Secondary } \\
\text { School }\end{array}$ & 22 & 9.3 & 15 & 19.2 & 5 & 6.8 & 42 & 10.8 \\
\hline $\begin{array}{l}\text { Tertiary } \\
\text { School }\end{array}$ & 10 & 4.2 & 9 & 11.6 & 68 & 91.9 & 87 & 22.4 \\
\hline \multicolumn{9}{|l|}{ Ethnicity } \\
\hline Yoruba & 231 & 97.9 & 78 & 100 & 74 & 100 & 383 & 98.7 \\
\hline Hausa & 2 & 0.8 & - & - & - & - & 2 & 0.5 \\
\hline Igbo & 3 & 1.3 & - & - & - & - & 3 & 0.8 \\
\hline \multicolumn{9}{|c|}{ Household Size } \\
\hline $1-2$ & 4 & 1.7 & 2 & 2.6 & - & - & 4 & 1.5 \\
\hline $3-4$ & 12 & 9.3 & 16 & 20.5 & 10 & 13.5 & 38 & 9.8 \\
\hline $5-6$ & 36 & 29.7 & 56 & 71.8 & 64 & 86.5 & 156 & 40.2 \\
\hline 7 and above & 184 & 78.0 & 4 & 5.1 & - & - & 188 & 48.5 \\
\hline Total & 236 & 100 & 78 & 100 & 74 & 100 & 388 & 100 \\
\hline
\end{tabular}

\section{Physical Characteristics}

Findings revealed that the available type of dwelling units in the study area is Brazilian types, compound/traditional, bungalow, flats and duplex. The survey revealed that $35.3 \%$ resides in compound unit, e study area. Further analysis of this result in disaggregated manner showed that the majority (57.6\%) of the respondents live in compound house in zone A, $48.7 \%$ and $63.5 \%$ of the respondents' lives in storey building in zone $\mathrm{B}$ and zone $\mathrm{C}$ respectively.

Age has a significant impact on the structural condition of a building, this is because building become obsolete and worn-out after many years due to wear and tear on its parts. Characteristically, buildings in the core of any city are expected to be the oldest in the settlement. As would be expected, the age structure of buildings that fall from 50 years and above according to this study is $67.4 \%$ of the building were built between 40 years and above in zone A, $41 \%$ represent the number of buildings that were between $20-29$ years ago in zone B while $82.4 \%$ represent the number of buildings constructed less than 10years ago in zone C. 
The noticeable material of construction in this part of the community is mud, sandcrete stones and mud bricks. As shown in Table 3, the highest proportion $69.5 \%$ of the houses in zone A were built with ordinary mud, $75.6 \%$ and $97.3 \%$ of the houses in zone $\mathrm{B}$ and zone $\mathrm{C}$ were built by sandcrete. The implication is that we have more of new buildings in both low and medium densities than high density zone in the study area.

Findings revealed the general state of roofing materials in the study area. For instance, the most common roofing material turned out to be corrugated iron sheet with $95.3 \%$ and $92.3 \%$ in zone A and zone respectively, and most of the roofs are not in good condition from personal observation during the course of this study. In contrary, majority $(77.3 \%)$ of roofing material used in zone $\mathrm{C}$ turned to be aluminum. The roof appearance are characterized by rusting galvanized iron sheet, many of which are already leaking and some roofing members are equally falling off from the woods holding them especially in high density zone.

Condition of the building can be measured by considering whether the wall is rendered with cement, painted, or the building wall has been left un-reconditioned (neglect due to repainting, re-rendering for a very long time). There is low level of maintenance of wall in zone A as shown in the Table 3 below. For instance, most $(91.1 \%)$ of the walls were cracked and indeed calling for immediate repairs in zone A. However, these buildings are regarded as poor. The houses which had cracks that had been mended are classified as fair; this account for $87.2 \%$ of the total buildings in zone B. In zone $\mathrm{C}$, majority $(89.2 \%)$ of the buildings were structurally sound Table 3 .

Table-3. Physical characteristics.

\begin{tabular}{|c|c|c|c|c|c|c|c|c|}
\hline Ratings & $\begin{array}{l}\text { Zone A } \\
\text { (High } \\
\text { Density) } \\
\text { Frequency }\end{array}$ & $\%$ & $\begin{array}{l}\text { Zone B } \\
\text { (Medium } \\
\text { Density) } \\
\text { Frequency }\end{array}$ & $\% \mathrm{e}$ & $\begin{array}{l}\text { Zone C } \\
\text { (Low } \\
\text { Density) } \\
\text { Frequency }\end{array}$ & $\%$ & Total & $\%$ \\
\hline
\end{tabular}

\begin{tabular}{|c|c|c|c|c|c|c|c|c|}
\hline \multicolumn{9}{|c|}{ Type of dwelling } \\
\hline Compound & 136 & 57.6 & 1 & 1.3 & - & - & 137 & 35.3 \\
\hline Brazilian & 68 & 28.8 & 6 & 7.7 & 3 & 4.1 & 77 & 19.8 \\
\hline Bungalow & 21 & 8.9 & 23 & 29.5 & 15 & 20.2 & 59 & 15.2 \\
\hline Storey & 11 & 4.7 & 38 & 48.7 & 47 & 63.5 & 96 & 24.8 \\
\hline Duplex & - & - & 10 & 12.8 & 9 & 12.2 & 19 & 4.9 \\
\hline \multicolumn{9}{|c|}{ Age of the buildings } \\
\hline $\begin{array}{l}\text { Less than } 10 \\
\text { years }\end{array}$ & 1 & .4 & 1 & 1.3 & 61 & 82.4 & 63 & 16.2 \\
\hline $10-19$ & 20 & 8.5 & 9 & 11.5 & 5 & 6.8 & 34 & 8.8 \\
\hline $20-29$ & 27 & 11.4 & 28 & 35.9 & 4 & 5.4 & 59 & 15.2 \\
\hline $30-39$ & 159 & 67.4 & 32 & 41.0 & 3 & 41 & 194 & 50.0 \\
\hline $\begin{array}{l}40 \text { years and } \\
\text { above }\end{array}$ & 29 & 12.3 & 8 & 10.3 & 1 & 1.4 & 38 & 9.8 \\
\hline
\end{tabular}

\begin{tabular}{l|l|l|l|l|l|l|l|l}
\hline Materials for construction \\
\hline $\begin{array}{l}\text { Ordinary } \\
\text { mud }\end{array}$ & 164 & 69.5 & 4 & 5.1 & - & - & 168 & 43.9 \\
\hline Brick mud & 63 & 26.7 & 15 & 19.2 & 2 & 2.7 & 80 & 20.6 \\
\hline Cement & 9 & 3.8 & 59 & 75.6 & 72 & 97.3 & 140 & 36.1 \\
\hline
\end{tabular}

Roofing materials

\begin{tabular}{l|l|l|l|l|l|l|l|l}
\hline Iron sheet & 225 & 95.3 & 72 & 92.3 .3 & 3 & 4.1 & 300 & 77.3 \\
\hline Asbestos & 11 & 4.6 & 4 & 5.1 & 15 & 20.3 & 30 & 7.7 \\
\hline Aluminum & - & - & 2 & 2.6 & 56 & 75.7 & 58 & 15.0 \\
\hline Condition of wall & 1 & .4 & 1 & 1.3 & 66 & 89.2 & 68 & 17.5 \\
\hline Good & 1 & 8.5 & 9 & 11.5 & - & - & 29 & 7.5 \\
\hline Cracked & 20 & 91.1 & 68 & 87.2 & 8 & 10.8 & 291 & 75.0 \\
\hline Patched & 215 & 100 & 78 & 100 & 236 & 100 & 388 & 100 \\
\hline Total & 74 &
\end{tabular}

Source: Field Survey, 2016.

\section{Adequacy of Building Facilities}

In order to examine these, respondents were to express their opinion using Likert scales of 'Regularly'; 'inadequacy' and 'not available for building facilities. To arrive at "Rating value”, a weighted eight value of 3,2 and 1 were respectively attached. The rating value was arrived at by dividing the Summation of Rating Value (SRV) by the total number of responses. The SRV for each factor was obtained through the addition of the product of the number of responses to each factor and the respective weight value attached to each rating. This is mathematically expressed as: 
$\sum_{i=1}^{3}$

$\mathrm{SRV}=x_{i} y_{i}$

Where:

$\mathrm{SRV}=$ Summation of Rating value;

$x_{i}=$ number of respondents to rating $\mathrm{i}$;

$y_{i}=$ the weight assigned to a value $(\mathrm{i}=1,2,3)$.

The index for each thus takes a value of between 3 and 1.

Rating $=\frac{S R V}{\sum_{i=1}^{3}}$

Therefore, the details of the findings are summarized below.

From the summary presented in Table 4, findings showed that the most adequate building facilities in the study area were toilet facility. The adequacy rating computed was 3.64. Next to this was kitchen facility with adequacy rating of 3.55. The least in adequacy was septic tank (2.69) and next to this was a drainages facility (2.90). Respondents were of the opinion that bathroom and soak way pit were moderately available or adequate. Adequacy of building facilities somehow varies from one density to the other. From the analysis presented in Table 4, while the most adequate facility in the high density was bathroom, findings showed that it was toilet and Kitchen, respectively in the medium and low density residential areas. However, findings revealed septic tank as the least adequate in the high, medium and low densities. Similarly, drainage was rated second to the least adequate in these three residential densities. Furthermore, soak away pit was appraised third to the least adequate in these three residential densities (A, B and C) Table 4.

Table-4. Adequacy of building facilities.

\begin{tabular}{l|l|l|l|l|l|l|l}
\hline \multicolumn{2}{l|}{ High Density } & Medium Density & Low density & Ede Town \\
\hline Sources & Rating & Sources & Rating & Sources & Rating & Sources & Rating \\
\hline Bathroom & 3.64 & Toilet & 3.56 & Kitchen & 3.62 & Toilet & 3.64 \\
\hline Kitchen & 3.57 & Bathroom & 3.54 & Toilet & 3.56 & Kitchen & 3.55 \\
\hline Toilet & 3.44 & Kitchen & 3.31 & Bathroom & 3.32 & Bathroom & 3.38 \\
\hline Soak away pit & 3.05 & Soak away pit & 3.07 & Soak away pit & 3.01 & Soak away pit & 3.04 \\
\hline Drainage & 2.91 & Drainage & 2.91 & Drainage & 2.91 & Drainage & 2.90 \\
\hline Septic tank & 2.67 & Septic tank & 2.64 & Septic tank & 2.70 & Septic tank & 2.69 \\
\hline
\end{tabular}

However, in determining the relationship between household-size and overall housing quality, the proposed null hypothesis stating that "there is no significant relationship between users' household-size and housing quality in Ede was tested using the Analysis of Variance (ANOVA). By comparing the mean values for these variables, the test yielded an F-ratio of 14.55 at less than 0.05 level of significance (i.e. $P=0.000$ ), Table 5. This result indicates that household-size has a significant influence on the overall housing quality in Ede. Significantly, this finding rejects the null-hypothesis and validates the hypothesis that there is a significant relationship between household-size and housing quality in Ede, Nigeria.

While substantiating Muller (1984), Onibokun, (1985), Jiboye (2010), Yoade (2012) and several others, on the imperativeness of socio-cultural parameters to housing, the finding justifies the need to consider the structure of families and size of households of the different sub-cultures when deciding on qualitative housing provision in Nigeria.

Table-5. Relationship between Household-Size and Overall Housing Quality in Ede.

\begin{tabular}{l|l|l|l|l|l}
\hline Source of variation & $\begin{array}{l}\text { Sum of } \\
\text { Square }\end{array}$ & Df & $\begin{array}{l}\text { Mean } \\
\text { Squares }\end{array}$ & F & Sig \\
\hline Between Group & 345.22 & 3 & 921.08 & 14.55 & .000 \\
Within Groups & 42561.89 & 489 & 95.65 & & \\
Total & 47463.91 & 495 & & \\
*Significant $(\mathrm{P}<0.05)$.
\end{tabular}


A further attempt was made using a multiple comparison (post hoc) test to determine the zone having the highest variation in the pattern of housing quality. The findings revealed that zone A has a greater mean value of 49.63 than zones B and C (43.16 and 42.19) while that of zones A and B are not statistically different from each other Table 6.

Table-6. Multiple comparison of mean values of pattern of overall housing quality among three residential zones in Ede.

\begin{tabular}{|c|c|c|c|c|c|c|}
\hline Pattern of housing quality & $\mathbf{N}$ & $\mathbf{X}$ & SD & $\begin{array}{l}\text { Mean } \\
\text { difference }\end{array}$ & Std error & $\mathbf{P}$ \\
\hline 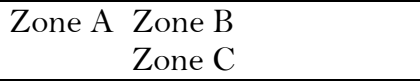 & $\begin{array}{l}78 \\
74 \\
\end{array}$ & $\begin{array}{l}43.16 \\
42.19 \\
\end{array}$ & $\begin{array}{l}6.32 \\
5.12 \\
\end{array}$ & $\begin{array}{l}-4.43^{*} \\
-1.95\end{array}$ & $\begin{array}{l}1.037 \\
1.008 \\
\end{array}$ & $\begin{array}{l}.000 \\
.362 \\
\end{array}$ \\
\hline $\begin{array}{r}\text { Zone B Zone A } \\
\text { Zone C }\end{array}$ & $\begin{array}{l}236 \\
74\end{array}$ & $\begin{array}{l}49.63 \\
42.19\end{array}$ & $\begin{array}{l}8.19 \\
5.12\end{array}$ & $\begin{array}{l}-5.43^{*} \\
1.95\end{array}$ & $\begin{array}{l}1.782 \\
1.008 \\
\end{array}$ & $\begin{array}{l}.000 \\
.362 \\
\end{array}$ \\
\hline $\begin{array}{r}\text { Zone C Zone A } \\
\text { Zone B }\end{array}$ & $\begin{array}{l}236 \\
78\end{array}$ & $\begin{array}{l}49.63 \\
43.16\end{array}$ & $\begin{array}{l}8.19 \\
6.32\end{array}$ & $\begin{array}{l}5.43 \\
4.43^{*}\end{array}$ & $\begin{array}{l}1.782 \\
1.037\end{array}$ & $\begin{array}{l}.000 \\
.000\end{array}$ \\
\hline
\end{tabular}

\section{Conclusion and Recommendation}

This study examined the incidence of poor housing quality in Nigeria and the negative effects emanating from it. It notes the occurrence of rapid rate of urbanisation occurring in the country, the consequences of which have been severely degenerated urban environment. The study concluded that household size of families is paramount when deciding on qualitative housing providing and sustainable urban growth and development.

However, the study recommends that the overall quality of the existing housing stock and environment could be improved through government intervention in the form of compulsory rehabilitation and urban renewal programs. This will invariably improve the quality of life of residents in the study area. Also, a periodical review of the master plan of study area is advocated. Reviews of master plans are necessary to monitor the growth of towns and cities, thereby control spontaneous developments that are detrimental to the well-being of residents and the estates. This should be implemented to update and regularize changes in the master plan to incorporate uses that are hitherto absent in the plan due to their significances.

\section{References}

Abloh, F. A. (1980). A concise in basic sociology for community designers. Department of Housing and Planning Research, University of Science and Technology, Kumasi, Ghana.

Abiodun, J. O. (1985). The provision of housing and urban environmental problems in Nigerian. Urban and Regional Planning Problems in Nigeria;(Ed.) J.O. Abiodun, University of Ife Press Ltd. pp: 174-194.

Adeleye, O. (2012). Residents` perception of the effect of development control activities on housing qualities in ife central local government, Ile-Ife, Nigeria. Journal of Social Science, 1(24): 1- 12.

Aduda, G. T. (2002). The cost of corruption in the development and management of the city in Nigeria, in Amole, D. et al (eds) The City in Nigeria: Perspectives, Issues, Challenges and Strategies, Proceedings of the National Conference organised by the Faculty of Environmental Design and Management, Obafemi Awolowo University, Ile-Ife, November 9 - 11, 2002.

Afon, A. (2000). Use of residents environment quality indicator (EQI) data in a residential housing improvement, In Effective Housing in the 21st century, Nigeria. The Environmental Forum, F.U.T.A. pp: $115-122$

Agbola, T. (1998). The housing of Nigerians; a review of policy development and implementation. Research Report 14, Development Policy Centre, Ibadan, Nigeria.

Agbola, T. \& Agunbiade, E. (2007). Urbanization, slum development and security of tenure: The challenges of meeting millennium development goal (MDG 7) in Metropolitan Lagos, Nigeria. Paper Presented to the PRIPODE Workshop, Nairobi, Kenya. 11 - 13, June.

Ebong, M. O. (1983). The perception of residential quality: A case study of Calabar, Nigeria. Third World Planning Review, 5(3): 273-285.

Foster, A. (2000). Putting your house in order: evaluating tenant satisfaction with improvements to social housing. Available from: http://www.hmtreasury.gov.uk/media/092FE/239.pdf. [Accesssed April 8, $2010]$.

Goffman, E. (1959). The presentation of self in everyday life. Garden City, N. Y.: Doubleday.

Gyuse, T. T. (1993). Socio-cultural dimensions of public housing in urban development in Nigeria planning, housing and land policy. Edited by Robert W. Taylor (1993). Montclair State, New Jersey, U. S. A. Published by Ave Burry, U. S. A. pp: 154.

Hanmer, L., Booth, D. \& Lovell, E. (2000). Poverty and transport: A report prepared for the world bank in collaboration with DFID. Overseas Development Institute.

Ilesanmi, A.O. (2005). An evaluation of selected public housing schemes of Lagos State development and property corporation, Lagos Nigeria. Thesis Submitted for the award of $\mathrm{PhD}$ in Architecture at the 
Department of Architecture, Faculty of Environmental Design and Management Obafemi Awolowo University(OAU) Ile-Ife, Nigeria

Jiboye, A. D. (2004). An assessment of the influence of socio-cultural factors on housing quality in Osogbo, Osun State, Nigeria. An Unpublished M.Sc. Thesis, Department of Urban and Regional Planning, Obafemi Awolowo University, Ile-Ife.

Jiboye, A. D. (2009a). The challenges of sustainable housing and urban development in Nigeria. Journal of Environmental Research and Policies, 4(3): 23-28.

Jiboye, A. D. (2009b). The significance of households' characteristics on housing quality in Nigeria. Journal of Geography and Planning Sciences, 2(2): 1-10.

Jiboye, A. D. (2009c). The relevance of house-form to housing quality in Nigeria. International Journal of Sustainable Development, 2(3): 29-36.

Jiboye, A.D. (2010). Correlates of public housing in Lagos, Nigeria. Journal of Geography and Regional Planning, 3(2): 17-28.

Lewin, A. (1981). Co-operatives in developing countries. International Technology Publication Ltd.

Lucas, R. (1990). Why doesn't capital flow from rich to poor countries? American Economic Review 80(2): 9296.

Muller, M. S. (1984). Traditional cultural identity in new dwellings of urban Africa. Ekistics, 51(307): 359 365.

National Housing Policy (NPC), (2006). Sustainability; policy areas. Available from: http://www.housingcorp.gov.uk. [Assessed March, 5, 2009].

Olayiwola, L. M., Adeleye, O. A. \& Jiboye, A. D. (2006). Effect of socio-cultural factors on housing quality in Osogbo, Nigeria. A Paper Presented at the International Symposium on Construction in Developing Economies: New Issues and Challenges, Working Commission W107 Construction in Developing Countries, 18 - 20 January 2006, Santiago, Chile.

Olayiwola, L. M., Adeleye, O. A. \& Ogunshakin, L. (2005). Public housing delivery in Nigeria: Problems and challenges, world congress on housing: Transforming Housing Environments through the Design, September 27 - 30 2005, Pretoria, South Africa.

Olotuah, A. O. (2006). Housing quality in suburban areas: An empirical study of Oba-Ile, Nigeria. Dimensi Teknik Arsitektur, 34(2): 133 - 137.

Onibokun, P. (1985). Socio-cultural constraints on urban renewal policies in emerging nations. The Ibadan Case. In: Housing in Nigeria. P.Onibukun (Ed.). A Book of Reading (NIER), Ibadan. pp: 393-405.

Onibokun, A. G. (1982). Issues in Nigerian housing, NISER, Ibadan.

Sholamith, K. (2000). United Nations committee on economic, social, cultural development and commitments made at earth summit in Rio. The People's Movement for Human Right Education (PDHRE).

UN-Habitat, (2006). Regulatory framework and strategic urban planning and management. A Paper Presented at the African Ministerial Conference on Housing and Urban Development in Nairobi, April $3-4$, 2006. Available from: http://www.unhabitat.org. [Assessed October 3, 2008].

United Nations, (1996). The right to adequate housing. Centre for Human Rights, Geneva.

UNICEF, (2001). State of the world's children. UNICEF, New York, 2001.p.16

Yoade, A.O. (2012). Socio-cultural challenges to urban renewal in Ile-Ife, Nigeria; An Unpublished M.Sc. Thesis, Department of Urban and Regional Planning, Obafemi Awolowo University, Ile-Ife, Nigeria

Yoade, A.O., Olayiwola, L.M. \& Popoola, K.O. (2013). Socio-cultural Challenges to Urban Renewal in Ile-Ife, Nigeria. Online Journal of African Affairs; 2(1): 10-18.

Yoade, A.O. \& Adeyemi, O.O. (2015). Influence of inner-city decay on residents' health in Ile-Ife, Nigeria. Journal of Environment and Earth Science, 5(18): 137-145. 